same configurational change, since after titration with acid at $38.5^{\circ} \mathrm{C}$., both the 6 -keto and 6 -amino groups jonize without hysteresis.

These results show that ribonucleic acid in solution may be present in one of at least two configurations depending on ionic strength, $p \mathrm{H}$, and temperature. The transition from one configuration to another may be impeded as shown by the hysteresis in the titration cycle. These observations could be accounted for if rotations about the linkages of the sugar phosphate back-bone were sterically hindered. It is possible that one configuration may be stabilized by sequences of intra-molecular bonds, although the sedimentation velocity and intrinsic viscosity of $E$. coli (and also tobacco mosaic virus ribonucleic acid) are consistent with a randomly coiled configuration. Further experiments are required to elucidate the configurations indicated above and to determine the extent to which they may reflect the in vivo structure ${ }^{8}$ found for ribonucleic acid in nucleoproteins.

This research was supported in part by a U.S. Public Health Service research grant $R G-5217$.

$$
\text { R. A. Cox }
$$

$$
\text { U. Z. LitTauer }
$$

The Weizmann Institute of Science, Rehovoth, Israel.

$$
\text { June } 23 .
$$

${ }^{1}$ Eisenberg, H., and Littauer, U. Z., Bull. Research Council of Israel, 7 A, 115 (1958)

${ }^{2}$ Littauer, U. Z., and Eisenberg, H., Biochim. Biophys. Acta, 32, 320 (1959).

saskov, R., Margoliash, E., Littauer, U. Z., and Eisenberg, H., Biochim. Biophys. Acta, 33, 247 (1959).

4 Conway, B. E., J. Polymer Sci., 18, 265 (1955).

Cox, R. A., Ph.D. Thesis, Birmingham (1955).

6 Cox, R. A., Jones, A. S., Marsh, G. E., and Peacocke, A. R., Biochim Biophys. Acta, 21, $576(1956)$

? Gierer, A., Z. Naturf, 13b, 477 (1958).

Franklin, R. E., Klug, A., Finch, J. T., and Holmes, K. C., Disc. Farad. Soc., 25 (1958).

\section{Glyceric Acid in Broad Bean (Vicia faba L.)}

IN recent years there have been one or two reports of the occurrence of free glyceric acid in higher plants. Balansard ${ }^{1}$ identified the acid as the diuretic principle in the pods of broad bean (Vicia faba L.) but gave no indication of the amount present other than could be inferred from the diuretic effect. Isherwood, Chen and Mapson ${ }^{2}$ isolated D-glyceric acid from cress seedlings; they found that it was present in arnounts ranging from 5 to $50 \mathrm{~m}$. equiv. $/ \mathrm{kgm}$. of fresh weight in seedlings cultured for 5 days at $20^{\circ} \mathrm{C}$. in the dark on $0.04 M$ sodium bicarbonate solution. Palmer ${ }^{3}$ isolated D-glyceric acid from tobacco leaves (Nicotrana tabacum var. Connecticut) grown in the shade and estimated the quantity present to be of the order of $5-15 \mathrm{~m}$. equiv./ $\mathrm{kgm}$. (fresh weight).

We have recently determined the levels of $\mathrm{D}$-glyceric acid in leaves and other parts of broad bean plants grown under various conditions and the results (Table I) show that it is one of the major organic acids accumulated by the plant.

\begin{tabular}{|c|c|c|c|c|c|}
\hline Sample & Description & Origin & Matic & Citric & Glyceric \\
\hline $1 \mathrm{a}$ & leaves & Field & $6 \cdot 6$ & $2 \cdot 4$ & $28 \cdot 7$ \\
\hline b & stems & Field & $13 \cdot 7$ & $15 \cdot 6$ & $33 \cdot 4$ \\
\hline $2 \mathrm{a}$ & leaves & Water culture & $12 \cdot 8$ & $48 \cdot 0$ & $23 \cdot 5$ \\
\hline b & stems & Water culture & $31 \cdot 4$ & $27 \cdot 5$ & $34 \cdot 0$ \\
\hline $3 a$ & roots & Pot grown & $1 \cdot 3$ & 0.45 & $1 \cdot 10$ \\
\hline b & leaves (young) &,,$\quad$, & $10 \cdot 8$ & $36 \cdot 7$ & $44 \cdot 9$ \\
\hline $\mathrm{e}$ & leaves (old) & ," & $8 \cdot 5$ & $73 \cdot 8$ & $24 \cdot 4$ \\
\hline d & stems & ", & $13 \cdot 5$ & $19 \cdot 7$ & $34 \cdot 7$ \\
\hline e & flowers & ," & $16 \cdot 4$ & $3 \cdot 7$ & $6 \cdot 6$ \\
\hline i & pods &, & & & \\
\hline
\end{tabular}

Table 1. Princhele Organid Acins in Vicia jaba L. (m.cquiv./kgm. fresh weight)
The acids were extracted from the plant tissue and determined by titration after separation by partition chromatography on a column of silica gel according to methods already described ${ }^{4}$. Recovery of glyceric acid under those conditions is practically quantitative. It is however poorly separated from shikimic acid. The two acids are however readily separated by paper chromatography ${ }^{2}$ and distinguished by the characteristic colour reaction ${ }^{5}$ given with sodium nitroprusside and piperazine after oxidation with periodate. No shikimic acid could be detected in these extracts.

The identity of the D-glyceric acid was established by isolation as the crystalline calcium salt after being separated from other acids by partition chromatography on silica gel followed by ion-exchange chromatography on 'Dowex 1' (acetate form) ${ }^{6}$. The calcium salt had $[\alpha]_{\mathrm{D}}{ }^{18^{\circ}}+12 \cdot 8^{\circ}(c, 4$, water $)$ and its infrared spectrum was identical with that of an authentic sample of calcium D-glycerate prepared by resolution ${ }^{7}$ of DL-glyceric acid obtained by the oxidation of glycerol ${ }^{8}$.

\section{R. I. Morrison}

P. C. DEKoCK

Macaulay Institute for Soil Research, Craigiebuckler, Aberdeen. May 18.

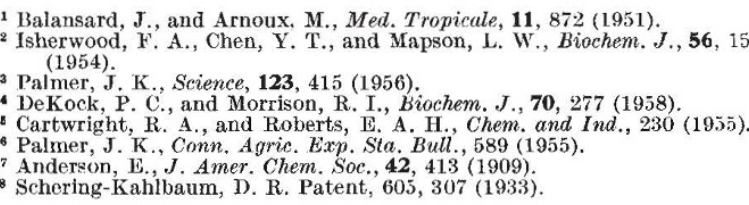

\section{Partial Identification of Lysins and Agglutinins in Lymphomatous Mouse Tissue}

Lysins and agglutinins have been extracted from normal mouse tissue, from mammary carcinomas of female $C 3 H$ mice, and recently from human leukæmic cells $^{1}$, and from the lymphomatous glands of $A K R$ mice $^{2}$. The lytic materials have been tentatively termed 'soap-like' and 'lysolecithin-like', supposedly bound to proteins ${ }^{3,4}$, but in reality the nature of both the lysins and the proteins is still unknown. This communication is concerned with the last point.

The methods of 'pre-incubation' and of extraction with organic solvents have been largely abandoned because they probably involve the splitting of complexes. Instead, lymphomatous tissue is removed from the $A K R$ mouse, placed in saline in the proportion of $1 \mathrm{gm}$. of tissue to $3 \mathrm{ml}$. of saline, and immediately homogenized for 5 minutes in a 'VirTis' homogenizer at 23,000 r.p.m. Gross particles are immediately removed by slow centrifugation. Examination of the supernatant fluid with phase contrast shows innumerable myelin forms and tiny fragments. The supernatant fluid of the homogenate, after the throwing down of the gross particles, is diluted in powers of 2 with Michaelis buffer at $p \mathrm{H} \mathrm{8.5.}$ Washed mouse or human red cells are added and both inhibitors (in the less diluted homogenates) and lysins are observed within 3 hours at $37^{\circ} \mathrm{C}$.

Identification of the lysins. The homogenate, after the removal of the gross particles, is placed on a strip of fat-free filter paper so that it spreads over about I cm. The paper is dried at $56^{\circ} \mathrm{C}$.; saturated rhodamine $B$ in benzene and 1 per cent uranyl acetate are added to the paper $(a)$ in the region to 